\title{
Agitations for Regime Change and Political Restructuring: Implications on National Integration and Development in Nigeria
}

\author{
Igboke C. Shedrack \\ http://dx.doi./org/10.4314/ujah.v21i3.1
}

\begin{abstract}
The formation of organizations at global, regional and sub-regional levels among nation-states, especially after the World War II in 1945 was to nip in the bud situation that could escalate into war and promote global peace. It was also to promote political, economic and socio-cultural unity and welfare among member states. It was on this premise that the United Nations (UN), organizations of Africa Union
\end{abstract} (OAU) now AU, Arab League, European Union (EU), etc were formed to promote unity among nation states. The main thrust of this paper was to analyze the implications of agitation by various ethnic groups on national integration and development in Africa. The paper also $x$-rays the nexus between leadership failure and development in Nigeria. The study was anchoreOd on the structural functionalism theory to address agitations and conflict among ethnic groups in Nigeria. This theory recognizes the need for restructuring the political system that will enable each component unit to function effectively for sustainable development. The study relied on much of the data scooped from secondary sources such as textbooks, internet materials, magazines, newspaper, journals etc. The study found out that agitations and conflict among ethnic groups was threat to national integration and development, citing the case of Indigenous people of Biafra popularly known as IPOB, Niger Delta militant, etc. The paper concluded that national integration was the bedrock to peace and national development in Nigeria. It was also recommended that government should desist from the actions and inactions that are threat to national integration and peace. The study recommended that 
Nigerian government should seriously focus on empowerment and investment in youth, through education, skill acquisition and also implementing policy that will eliminate all forms of agitations. The paper equally recommended adoption of regional government and true Federalism to address the problems of national development.

Keywords: Agitations, regime change, political restructuring, integration, and development.

\section{Introduction}

Agitation for political restructuring in Nigerian polity is not a new phenomenon. It started after the amalgamation of the Northern and Southern protectorate in 1914 by Lord Lugard and the division of the country into three uneven sizes by Arthur Richard constitution in 1946, by making Northern region larger than the Western and Eastern region put together. As a result, it is difficult if not impossible to work together to achieve a common goals and promote national integration. Giving credence to this, the three major political parties formed before independence was regionally based. For example, the Northern people's congress (NPC) for the North, the leader was Alhaji Ahmadu Bello, the National Council of Nigeria and the Cameroon (NCNC) for the East, Dr. Nnamdi Azikiwe was the leader, while the Action Group (AG) for the West, Chief Obafemi Awolowo was the leader as well. They had regional support and ethnic loyalty. The political parties were without national outlook. However, the division of the country into unequal parts and other issues in Richard's constitution of 1946 leads to protest delegation to London to the secretary of state to colonies by the leaders of the NCNC led by Dr. Nnamdi Azikiwe. In order to address the problems, the secretary of the state for the colonies removed Arthur Richard and appointed John Macpherson as a Governor of Nigeria in 1948. As a result of this, John Macpherson (the Governor) embarked on wide consultations at various levels of 
village, town, provincial, region and national levels for Nigerians to agree to constitutional changes and later debated at the general conference held in Ibadan in January 1950, yet the changes in the constitution did not address the problems (Okwondu, 1979). In this regard, Oliver Lyttleton, the colonial secretary of state for the colonies then informed the British House of commons on May 21, 1953 about the situation in Nigeria. Lyttheton maintained that the situation on ground had shown that the three regions could not work together in a federation as was then structured. The failure of 1951, 1954, 1957, 1958 and 1960 colonial constitution to address the problems of agitations for political restructuring in Nigerian polity after political independence in 1960 gave rise to the constitutional conference held in Lagos on July 25 and 26, 1963. The Nigerian political leaders met to discuss and settle constitutional issues that led to agitations across the country. The outcome of the conference led to creation of mid-west region in August 1963 and paved the way for the alteration of the existing regional boundaries that constitute problems. However, the defects of the Republican constitution of 1963 led to first military coup in Nigeria on January 15, 1966 and counter coup on July 29, 1966. While non- implementation of agreement reached between Gowon and Ojukwu at Abur in Ghana to address the problems led to civil war on July 6, 1967.

Furthermore, the agitations continued after June 12, 1993 presidential election that judged by both local and international observers as the most "freest and fairest" election ever held in Nigeria. As a result of ethic segment, the final result of the election was not announced by the General Ibrahim Babangida led government. The agitations across the country led to 1994/1995 constitutional conference by General Sani Abacha. However, the nonimplementation of Abacha's conference report in 1995, Obasanjo's conference report in 2005 and Jonathan's conference report in 2014 contributed to current agitations in the country for political 
restructuring and Referendum especially by the indigenous people of Biafra, otherwise known as IPOB.

According to the group (IPOB), the Nigeria Federal government is discriminating and marginalizing them, the Igbo people. "They went on to say that, I am not allowed to aspire to become the inspector General of police because I'm Igbo, I'm not allowed to become Chief of Army staff because I'm Igbo what sort of stupid country is that?" Kanu asks "why would any idiot want me to be on that sort of country" (Oduah, 2017).

However, this paper is divided, into five sections. Section one introduces the topic. Section two explains some concepts such as agitations, regime change, political restructuring, national integration, leadership and development section three of the paper discusses the implications of agitations on national integration. Section four analyzes the problems of national integration, while section five highlights the efforts made by federal government of Nigeria to promote national integration, conclusion and recommendations.

\section{Statement of the Problem}

Agitations for political restructuring in Nigerian polity started after amalgamation of the Northern and Southern protectorate in 1914 by Lord Lugard and the subsequent division of the country into three unequal parts by Arthur Richard in 1946, by making Northern region larger than western and Eastern regions put together as earlier noted (Adigwe, 1974). This was manifested and played in 1953 when Chief Anthony Enahoro tabled a motion in the House of Representatives for self-government for Nigeria in 1956. As a result of this motion, a member of the Northern people's congress (NPC) called for adjournment which made the Action Group (AG) and National council of Nigeria and Cameroons (NCNC) members stage a walk out after this stage a walk out (Lawal 1982). After this scenario, the session of Northern House of Assembly and House of Chiefs released 
an eight-point programme which if it had been implemented, would have led to the secession of North from Nigeria. Another threat of secession by Western region in 1954 was the proposal to separate Lagos State from Western region in which was rejected by the Egbe Omo Oduduwa in October 1954 after their meeting.

In this regard, the only secession threat that has been carried out in Nigeria since independence was that of the Eastern Region in May 1967 which made the Region to be declared as the Republic of Biafra. This led to the 30 months civil War that threatened the corporate existence of Nigeria. Recently, after 2015 general elections, there is surge in secessionist threat and agitation across Nigeria one of such groups involved is the indigenous people of Biafra (IPOB). The group and its leader, Mazi Nnamdi Kanu, are campaigning for an independent country of Biafra, made up of ethnic Igbo. IPOB claim that the Nigerian federal government is discriminating and marginalizing them, the Igbo people, especially after appointment of ministers and security heads by president Buhari".

However, as a result of protest in South Eastern states, there were clashes between IPOB members and the Nigerian security officials that led to dead of many persons, several injuries and burnt police station in Aba (www.premiumtimes com.). In one such protest of May $31^{\text {st }}$, 2016, more than five personnel of the Nigeria police were killed while several soldiers were wounded, Nigeria police vehicles were burnt down while several others of the Nigeria Army were vandalized (Ndube, 2016). In Line with this development, the Nigeria military on September 15, 2017 declared the IPOB a militant terrorist organization. Similarly, the south East Governors forum proscribed the activities of the indigenous people of Biafra, to stop the rising tension in the Zone. According to chairman of the forum, and governor of Ebonyi State, David Umahi, IPOB has lost its original ideal by causing unnecessary tension and killings in the south- East which has affected investment drive in the region (Eze 2017). The 
agitation for political restructuring from IPOB members has done more harm to the Zone than good.

\section{Research Methodology}

This study relied mainly on secondary sources of data drawn from text books, Journals, official publications, conference papers, internet materials, newspaper, magazines and official documentaries that are relevant to the work. The analysis of data was based on deductions from the issues raised in the paper in the light of available data gathered.

\section{Conceptual Review}

For the purpose of better understanding, it is convenient to explain basic issues underlying this work. It is also relevant to state that the locus and focus of our discussion would be based on the worldview of the Nigerian people as an exemplication in the course of this paper. Having made these remarks, it is essential to clarify these terms in order to understand their meaning.

\section{Agitation}

Agitation simply means public argument or action for social or political change in a country. For example, if people agitate for political reform, they protest in order to get it. In line with this premise, the Richards constitution of 1946 was expected to last for nine years, but this was impossible because the people continued to agitate for a responsible government.

In August 3, 1947, the National Council of Nigeria and the Cameroon (NCNC) sent a nine-man delegation to the secretary of the state for the colonies in London to lodge their protests against the provision of the Richard's constitution. This delegation was led by Dr. Nnamdi Azikiwe. In order to address the problem, the secretary of the state for the colonies removed Arthur Richard and appointed John 
Macpherson as a Governor of Nigeria in April 1948. The Governor and his Chief Secretary Mr. Hugh foot (now Lord Caradon) decided right from the beginning that they would not fall into the same trap as Sir Arthur Richards. The draft of the John Macpherson's constitution was debated at the local council level, at the level of leaders of thought and finally at a general conference held in Ibadan in January 1950. Unfortunately, Macpherson's constitution did not conclusively solve the problem of political disunity in the country. A leader at the conference saw themselves as representatives and spokesmen of their regions and hence the compromises arrived at weakened the power of the centre (Adigwe, 1974).

However, the subsequent constitutions that follows (Oliver Lyttleton of 1954) to 1999 constitution as amended failed woefully to address the problems of political agitations and threat of secession that started in 1954, after the proposal to separate Lagos state from Western region which was rejected by the Egbe Omo Odunduwu. Furthermore, agitation is the act of stirring up others to protest for political reform in a country.

\section{Regime Change}

Regime change is the transition from one political regime to another, especially through concerted political or military action, as was done in World War II to Italy, Germany, and Japan (also known as the Aixs powers). It is the replacement of one government regime with another through the assistance of foreign forces either direct or indirect. The case of Iraq in 2003, Libya in 2011, Egypt in 2013 are good examples of regime change. The term, regime change was popularized by two former US President, Bill Clinton and George W. Bush in reference to Saddam Hussein's regime in Iraq as earlier noted. The US has been involved in and assisted in the over throw of foreign governments without the overt use of U.S. Military force. However, such 
operations are tasked to the central intelligence Agency (CIA), North Atlantic Treaty organization (NATO), etc.

In this regard, regime change can be precipitated by revolution or a coup d'etat. The Rusian Revolution, the 1962 Burmese coup and 1990 collapse of communism in Eastern Europe, that is dissolution of the Easter Bloc are consummate examples. Another example of internally driven regime change is the establishment of the French fifth Republic (1958) and the federation of Australia. Finally, regime change refers to a change in political institutions or Laws that affect the nature of the system as a whole. For example, the end of the Bretton woods system was a regime change in the international system, as was the repeal of the national mandatory speed limit in the United States.

\section{Political Restructuring}

The concept of political restructuring is not a new term in Nigeria polity but it has been misinterpreted and misrepresented by political Jobbers, champion by unelectable and serial election losers in the ongoing democratic setting in Nigeria. Political restructuring simply means to change the political institutions the way it is organized that constituted agitations and secession threat in order to make it work more effectively to accommodate all sections or groups in the country. The removal of Arthur Richard as a result of agitation for political reform by the secretary of the state for the colonics in London and appointed Sir John Macpherson as a Governor of Nigeria in April 1948 is a good example of political restructuring, because the former constitution (Arthur Richard of 1946 did not consult Nationalist leaders before the constitution was issued.

According to Njakku (2016), political restructuring means rearrangement, reorganization or reformation of the polity. But in Nigeria, political restructuring mean different thing to different people, especially scholars, political elite and commentators. In 
corroboration, Njakku Further import that, to some, it is secret weapon by a section to break up the country so that others would not have access to the oil and gas resources, because the mainstay of the economy is available only in one part of the country. For them, political restructuring is a tool advocated by a section of the Nigerian elites that feel they have been shut out of the central government", thus, they say if they cannot be accommodated up there at the centre, power should be regionalized, so they can help themselves in their own enclaves as autonomous entities. For others, political restructuring is basically to re-organize, reform the Nigerian-bodypolitics to become more inclusive, grant regional/state autonomy, political equality, equity, state creation and equalization of states in the geo-political zones, and the practices of "true" federalism. According to Itumo and Nwobashi (2017),

... Most people perceive political restructuring as a means to over haul the polity, beginning from constitution amendment, regionalism, state creation to equalize all the geo-political zones, rotational presidency, and adopting fiscal/true federalism. They say the centre or federal government which is vested with the control of all resources is too powerful, that the way out is to return the ownership of these resources to states or geo-political zones which may then pay taxes to run the government at the centre.

However, the Loudest and vibrant advocates or proponents of political restructuring are the same people disgruntled, due to their lost in the 2015 general elections (Njakku, 2016). 


\section{National Integration}

The word integration suggests a process of structural linkage between two or more parts of a system or systems (Onwuka, 1982). Its essence can be discerned from the functionalist view of society. Anele (1990) captures the functionalist perspectives thus: functionalist sees human society as a social system comprising sub-units or independent parts. These sub-units are inter dependent on each other and are functionally interrelated. This implies that every phenomenon found in the society performs useful functions towards the survival of the entire system or society. It equally means that the sub-units of the society otherwise referred to as social institutions such as family, religion, polity, economic, education, technology, etc are integrated and inter dependent and all perform useful functions towards the survival and stability of the society.

From the above background, national integration is a process of creating a sense of national consciousness, uniqueness of identity and loyalty among people with different socio-cultural identities into a single territorial society. It also means the feeling of togetherness or oneness towards one's own country irrespective of their individual differences with regard to religion, region, race, culture. According Mezieobi (2014), National integration is the fusion of culturally, socially, politically, and ethnically disparate group of people in a given geo-political setting into a closely knit cohesive group involved in repetitive cordiality dominated human interaction geared towards building a territorial nationality. Shamaije and Nyiyongo (2012) describe national integration as the problem of creating a sense of territorial nationality, which overshadows or subordinates' parochial loyalties. It means that though we belong to different ethnic groups, religions, states or regions, and speak different languages, we recognize the fact that we are all one. 


\section{Development}

Development in the literature has been widely contested by various scholars because of its multi-dimensional nature. According to Adeyemo (2003), development is a process in which a system or institution is transformed into a stronger, more organized, more efficient and effective form and proves to be more satisfying in terms of human wants and aspirations. In this regard, Mittman (1988) define development as the increasing capacity to make national use of natural and human resources for social ends.

In line with this, Olaniyi (2009) described development as a" process of societal advancement where in improvements in the wellbeing of people are generated through partnership between all sectors of the population, the public and private sectors, corporate bodies and other groups in the society. The purpose of development is to eliminate poverty, provide people with jobs options and opportunities for sustainable livelihoods, empower people, particularly women, the children and disadvantaged and up their capacity to ensure their mobilization and participation as the latent force of development, and meet the needs of the country (Atere \& Kasim, 2003).

Seers (1969) raised three fundamental questions about a country's development. They are as follows: (1) What has been happening to poverty? (2) What has been happening to inequality? (3) What has been happening to unemployment? If all three of these have declined from high levels, then beyond doubt, this has been a period of development for the country concerned. But if one or two of these central problems have been growing worse, especially if he entire three have, it would be strange to call result development even if per capita income doubled. He further maintained that development occurs when solution to the problem of hunger, unemployment, disease, malnutrition etc. are found. This definition of development makes people the target or end of development. It is truism because development is not just all about growth but all about people. In this 
regard, Ake (1989) defined development as the process by which people create and recreate themselves and their life circumstances to realize higher levels of civilization in accordance with their own choices and values. It must therefore be conceived of as a multidimensional process involving major changes in social structure popular, attitudes and national institutions as well as the acceleration of economic growth, the reduction of inequality and the eradication of poverty. It must represent the whole gamut of change by which an entire social system, tuned to the divers basic needs and desire of individuals and social groups within that system, moves away from a condition of life widely, perceived as unsatisfactory toward a situation or condition of life regarded as materially and spiritually better (Todaro \& Smith, 2004).

Stiglitz (2000) argues that development should be seen as a transformation of society, a move from old ways of thinking, and old forms of social and economic organization to new ones. Development and developmental transformation involve a change in the way people think and the way societies function, a change in norms, expectations and institutions. Development involves not just the acceptance of change but its promotion and indeed, its routinization. Also, the UN's perspective of development emphasizes the power of the people to solve their own problems, with their own wisdom, experiences and resources. The participation by the people themselves in efforts to improve their level of living with as much reliance as possible on their initiative and the provision of technical and other services in ways which encourage initiative, self - help and mutual help is viewed as development.

\section{Theoretical Framework}

This work was anchored on structural functionalist theory which dates back to the works of August Comte (1798-1857) and Herbert Spencer (1820-1903). The theory was refined by Emile Durkheim (1858- 
1917) and Talcott Parsons (1902-1979) respectively other proponents of the theory like Radcliffe-Brown, Almond Gabriel, David Apter, William Mitchel, Robert Merton also did extensive work in order to develop the theory. Functionalism was dominant social theory in America sociology during the 1940s and 1950s as it views the society as a social system that is made up of different parts which are interdependent and interrelated. These different parts or sub-units of society are the family, school, church, government, economy, legal system, etc. perform various functions that produce positive effects towards the maintenance, stability and survival of the social system.

The theory however, during the 1950s and early 1960s witnessed a steady drop from the discipline of sociology partly because of the criticisms against it and advancement in sociological research. The concept was however, adopted in political science and specifically in the field of comparative politics. The concept sees the political system as interrelated and reciprocally regulated patterns of actions and orientation patterns that have needs for the maintenance and survival of the system. According Nwosu and Ofoegbu (1986), functions as generally used by scholars in political science refers to the contribution of an activity or patterns of behaviour to the maintenance of a system in a given society. Nwosu and Ofoegbu went further to import that; it is the observable effects of an activity that are necessary to the sustenance of the system. Function implies a positive contribution towards system maintenance, while dysfunction is used to refer to negative contribution that is, contributions that lead to the breakdown of the system.

In corroboration, Ekwuonna (2016) identify the following items as the basic assumptions of structural functionalism:

1. All element and structures are so because they perform specific and identifiable functions within the system. It is this quality that gives them identity as members of that system (only and not 
members of any other system). Outside of that system and their functions, these entities have no meaning, and, thus, do not exist.

2. The overall assessment of each element of the society is that it contributes to the stability and equilibrium of the society as a system, otherwise that element would not remain a part of the society (for long).

3. All tensions affect the whole system and, thus, each part of it, and the resolution of tensions affects the contemporary operations and the state of each part.

It is discernible from the above reference that plural societies like ours, with distinct ethnic nationalities operate as a system that requires each unit for the good of all. Thus, the different ethnic groups are the interrelated and interdependent sub-units that must function in unity.

Therefore, applying the structural functional theory to this study, it is imperative to understand that Nigeria is viewed as a whole system, and the different states or ethnic groups that make it up are like component parts that work in unison for peace, stability, equilibrium, development, synergy etc. Each state in Nigeria performs specific functions and this gives them identity. Hence, when threat of secession and agitations for political restructuring is perpetrated anywhere in Nigeria, it reverberates through the system and causes disruption in the economic, political, social, and cultural wellbeing of the system. Consequently, any efforts by the government of the states, either individual or collectively, to arrest the situation from escalating in the form of proscribed the group or other forms of measures definitely aimed at resolution of tensions to restore stability and equilibrium in the system.

\section{Problems of National Integration in Nigeria}

The greatest challenge facing Nigeria today is the threat to national unity, as centrifugal tensions, resource control and self-determination, 
ethnicity in the based identify politics and religious cleavage has enveloped national consciousness. Though, these problems started after the amalgamation of the Northern and Southern protectorate in 1914 by Lord Lugard and the sequent division of the country into unequal part by Arthur Richard in 1946 that lead to formation of regional political parties among the three regions.

According to Onyeoziri (2001) on the problems of national integration in relation to Nigeria, loyalty to the Nigerian state remains at best reluctant, while stability has continued to elude the system. Inter-communal or ethnic hostility and even open violence have increased while the constant complaint of marginalization tells its own story of the declining sense of belonging that exists in the land. These are eloquent symptoms that the policy of federal character is not producing the desired effect. In collaboration, Olufemi (2005) imports that the depth and dimension of this development are reflected in the rise and popularity of ethnic militias such as the Oduduwa People's Congress (OPC), Arewa People's Congress (APC), Ijaw Youths Congress, Movement for the Actualization of the Sovereign State of Biafra (MASSOB) which advocates secession. Olufemi further maintained that it is the above context that the agitation for "true federation" and political restructuring must be understood. However, it is because of this critical lack of national integration that the erstwhile Biafra leader, author and polemic, Emeka Odumegwu Ojukwu, declared sadly that: "The true problem with Nigeria is that, she is fully embroiled in an identity crisis. The Nigerian of today is a socio-path in search of a national programme. We live in a country in search of a common character" (Odumegwu Ojukwu, 1989).Other factors that discourage national integration in Nigeria are ethnic cleavage, economic underdevelopment or dependence and weak sense of nationhood arising from a short period of independent statehood (Ojo, 2009). Ojo further avers that the adoption of a federal system of government was supposed to address 
these serious conditions such as ethnic cleavage, but it does not seem to have worked well. A federal principle is even a difficult system to manage because element of diversity is very strong. In this regard, Charles Tarlton (1965), Donald Rothehild (1966) and other scholars analyse how the application of the federal principles is made difficult in Africa by the lack of crucial support for the principle from the key leaders, by the centralizing imperative of the modernization process and by the threat that the forces of ethnic intransigence and separation have posed to the continuance of the federal ties (cited in Ojo2009).Consequently, mis-governance and power struggle are other problems of national integration in Nigeria, as Ifidom (1996) rightly observed:

In Nigeria, competition for control of state power is as much as source as is a consequence of the failure of equitable government. At the root of the democratization, is not merely ethnic plurality but inequity. Inequity becomes a necessary feature of the relations among mobilized ethnic groups, and hence a multi-ethnic state is susceptible to democratic instability.

Giving credence to the above submission, Ake (1989) attributed the problem of governance to the circumstances our history, who conspired to produce an elite which cannot function effectively because it has no sense of identity or integrity and no confidence, does not know where it is coming from or where it is going. This had to do with Nigeria's long decline over the centuries and our domination by outsiders. It is clear from the behaviour of our leaders that control state resources. In that condition, the funds or grants meant for the development of the state are directed for private usage among the cabals who surround the president and Governors in the level. In this regard, Egwu (2005) imports that state played central and determinate role in the allocation of values and has indeed been a 
wealth mine where it became solely privatized for the appropriation of national resources. Bayart (1993) conveys this quite instructively when he observers that, African states are distinctively characterized by polities of the belly which is seen as the predatory pursuit, or rush for spoils of wealth and power, that is a model of governance takes historically specific forms appropriate to the post-colonial state in Africa. This generates incentives for leaders to "eat" from the resources of the state. It is clear from the foregoing observations that politics in Nigeria is a zero- sum game. The winner wins everything while the loser loses completely, even the safety of his life is not guaranteed. It is therefore important to win at all cost, irrespective of the heap of skulls and broken bones that litter the ground as monuments to that victory. In contrast, David west (2003) explains the difference between US (Nigeria) and the developed countries is that while the leaders are literally with every ticking off the clock seriously addressing the problems and concerns of the moment and finding solutions to them, in under developed Africa, leaders expend their energies more in devising more and more sophisticated machinery for subverting the system, economically or electorally.

However, the political problems of Nigeria since independence have been caused by abuses of power by president and states Governors rather than ethno- sectional competition. For instance, several states in the core North implemented the Sharia as substitute for state law. In the south west, Yoruba leaders have revived the idea of regional federalism, in the southeast, the Igbo governors have called for confederation in the south- south, ethnic federalism is back on the agenda (Onwudiwe, 2001). Ethnic particularism is the major cause of the problems of national integration in Nigeria since independence.

In the same perspective, Agu (1997) identified poverty as a problem of National Integration in Nigeria and describes the Nigerian economy as follows: 
Food was scarce and expensive, people died unaccountably, salaries were not paid to workers. Hospitals, universities, primary and secondary schools closed either because of nopayment of salaries or because people wanted increase or still because of student demonstrations. Government was seriously under attack. People did not want to know which government might be held responsible whether the past or present. So these displaced responses have had very serious impact on both generality of the people, and on the economy itself.

In line with this, Agu Further argued that the economy is bad, people are dying of hunger, there is mass unemployment and unpaid employment, inflation, hardship of all kinds abound. Majority of the people are no longer sleep for thought and want of what to eat. The constant rape of the nation's scarce resources by our leaders have left many Nigerians poor, while nature make all Nigerians rich because of abundant mineral resources. Poverty is a major cause of communal conflicts that are threat to national integration and national security. In the same view, Ebo (1997) argued that "national security cannot exist in a situation of high unemployment, gross inequality and chronic poverty, regardless of the quantity and quality of military hardware in the arsenal of the country concerned". As a result of this ugly situation, Omodia and Muhammed (2016) wrote that "in a nation where majority of its people live in abject poverty thus lacking basic necessities of life (food, clothing and Shelter), the people's peaceful co-existence for the realization of these necessities is effectively threatened or always endangered conflict and violent demonstrations will be the order of the days",

\section{Efforts toward National Integration in Nigeria}

National integration is a constitutional matter in Nigeria. It is a matter of primary concern and attention; and expedient in the achievement of 
unity and development of the country. Mezieobi (2014) wrote that, the absence of workable national integration in Nigeria has continued to threaten the corporate existence of Nigeria. Nigeria government has over the years made deliberate efforts to promote national integration. Her efforts have not achieved the desired result. Nigeria has a constitutional provision that legalizes and promotes national integration. Section fifteen (15) of the 2004 federal constitution of the Republic of Nigeria provides for the role of the state in encouraging and expediting national integration among the heterogeneous people and ethnic groups that made up the state. It is the desire of the state to give every Nigerian a sense of belongings' free from discrimination on the grounds of place of origin, sex, religion, status, ethnic or linguistic association or ties. It is desire to encourage mobility of people, goods and services throughout the federation, and to promote inter-marriage among persons of different ethnic origin, linguistic, religions or other sectional barriers.

Aside from constitutionalizing national integration, government has initiated programs and policies that will promote national integration such as:

The National Youth Service Corps Scheme: This was launched on the $22^{\text {nd }}$ may 1973 with a view to ensuring that Nigerian youth, irrespective of ethnic and religious backgrounds, should put one year of compulsory service to the fatherland, upon completion of university, polytechnic or college of education programme, and by so doing making youth corps members live with people from other ethnic groups, learn and understand their ways of life, tolerate and accommodate inter-ethnic differences and eschew prejudices (Mezieobi 2014: 88- 89).

The Quota System: This is a deliberate attempt by the federal government to give every Nigerian irrespective of tribe and religion a sense of belonging. It is an attempt to carry all the ethnic 
groups along, without any group perceiving themselves as marginalized or having been left out of scheme of things or patronages. Nigeria constitutionally adopted the quota system principle in admissions into post- secondary or tertiary institution as well as offices. The aim of this policy is to correct the marginalization of minorities.

The Federal Character Principle: This was established by the Federal Government to address problems of agitations. According to Njoku (2011. p441) Cited in Thom-Otuya and Vincent Eremie (2018) the principle is put in place "to reduce to the barest minimum incidences of dominance of any group(s) by another one in the scheme of things". The principle empowers the federal Government to ensure the representation in government of various ethnic groups that constitute Nigeria and by so doing reflect the people's plethora of diversity. A federal character commission has been put in place and given a legal backing via the constitution to promote the federal character mandate in the interest of Nigeria's national integration. The principle was first introduced in the 1979 constitution and has been retained by every constitution since then.

Creation of States: This was done to allay fear of major ethnic group dominating the minor ones. Nigeria started with three regional governments, which later metamorphosed to twelve (12) States, 19 States and now thirty- six (36) states with a federal capital territory (Abuja) and, seven hundred and seventy- four (774) local government areas. These local government areas were created to bring governance to many of the different ethnic groups door step and thereby reduce tension, agitations and pressures that have ethnic undertones (Mezieobi, pp. 90-91).

Mass Mobilization of Nigerian: This was an attempt by the federal government to promote national integration. It is hoped that 
national integration via the instrumentality of mass mobilization will drive Nigeria to greater development heights. Federal government put in place programs like Mass-Mobilization for SelfReliance, Economic Recovery and social Justice (MEMSER) to drive the process. The mass mobilization agenda is toward reorientating Nigerians on government programmes, values and ethical issues.

The effort of the federal government to achieve national integration has been a mere paper work structural outlook but, its objective of promoting national unity and sense of patriotism and national awareness and consciousness amongst the people has not been achieved. Okafor (2010:19) noted that "right from time till today, Nigerians have not seen themselves as one". In the same line of thought, Mezieobi (2014: 94) wrote:

"Inter- ethnic competition, conflict, violence, mistrust is still pervasive, appear to have defied any sustainable solution and have embarrassed Nigeria here and in the international arena. Every ethnic man in Nigeria looks at people from the other ethnic groups with jaundiced eyes, with suspicion in high tempo such that all inter- ethnic interactions command suspicion and have ethnic undertone".

Consequently, the above submissions show that the various efforts made by Nigerian government to address the problem of national integration have not achieved the desired result.

\section{Conclusion and Recommendation}

This paper threw light on the problems which prevent national integration and development in Nigeria that leads to the agitations for political restructuring. Nigerians have been experiencing ethnic and religious crises as a result of unequal division of the country which has really affected the political and economic developments of the 
country. The paper noted that several measures have been put in place by Nigerian government to address the problems of agitations and ensure national integration, but it has not achieved desired result. Based on the above submission, we recommend the following:

- True Federalism: Nigeria should adopt true federalism where all the states in the country will have the power to control resources within their jurisdiction pay tax to the federal government.

- Implementation of 2014 National Conference Report: It was the failure of General Gowon to implement the Aburi Agreement that led Nigeria into civil war from 1967 to 1970 . On coming back to Nigeria, Gowon was advised to denounce the agreement due to divergent interpretations given to the meeting. However, the implementation of 2014 reports will address the problems of agitations among various ethnic groups in Nigeria.

- Appointment into Government Agencies: All political appointments should be made to promote unity and ensure stability in the country. The Buhari appointments contribute to current agitations and threat of security in the country.

- Banning of Tribal Association: The National Assembly should pass a bill which will be signed into law by the President, banning all tribal associations in Nigeria. Examples, Ohaneze Ndi Igbo, Afrenifere, Northern Elders Forum, etc. of which ethnic sentiment is at the core of whatever they do.

- Discouragement of Ethnic Loyalty: Politicians should be banned from preaching ethnic loyalty as a means of winning election. Anybody caught in this act should be punished to serve as a deterrent to others wishing to whip up ethnic sentiments to achieve their self-interest. 
- Zoning of Presidency or Power Shift: The idea of zoning the presidency should be forgotten, since it reminds us of ethnic differences.

- Equitable Revenue Allocation: This is the fundamental basis for national stability and cohesion. Without equitable distribution of national cake, distrust will continue, crises of marginalization and neglect may assume more dangerous proportions.

- Unity in Diversity: Our political leaders should not emphasize on what make us different from one another. They should endeavour to highlight the similarities of the different ethnic group in Nigeria. Common experience should be our bond.

- National Merit Award: No attempt should be made to give it ethnic pasture; Quota system, federal character as presently practiced has a dubious value.

Against the backdrop, it is our belief that if the above recommendations are properly implemented, Nigerians will begin to enjoy peace which has eluded them, due to ethnic crisis and agitation.

\section{Igboke C. Shedrac}

Department of Political Science

Nnamdi Azikwe University

Awka, Nigeria

shedrachigboke21@gmail.com 


\section{References}

Adeyemo, A. M. (2003). Development and Under-development in a cooperating Perspective, Port-Harcourt: Amethy St. Press.

Adigwe, F (1974) Essential of Government for West Africa. Oxford University Press, London.

Agu, G. A. (1997). Some coping mechanism in a Depressed Economy. Mary-Dan Publishers, Enugu.

Ake, C. (1989). The Political Economy of Crisis and Underdevelopment: Selected Works of Claude Ake. Edited by Julius Ihornbere Lagos Fad Publishers.

Almond, Gabriel A. and Verba, Sydney (1963). The Civic Culture: Political Attitudes and Democracy in Five Nations. New Jersey: Princeton University Press.

Ebo, F. A. (1997). Food and national security in Nigeria. Journal of the Nigerian Defence Academy, 7(3) pp28-43.

Eze, R. (2017). International Law and Political Realism: Lessons for the Third World. Ekumax Company Limited, Anambra State.

Ifidon, Ehimika A. (1996) "Citizenship, statehood and the problem of Democratization in Nigeria." Afric Development. Vol. XXI. No 4.

Lawal, A (1982) "O" level Government of West Africa. Educational Book Nigeria Ltd, Nigeria.

Mezieobi, K. A (2014) ethnicity in Nigeria: De-ethicizing road map. Owerri, Priscilla Omana Publishers.

Ndibe, O. (2016). Biafra and the Business of killing. Retrieved on October 12, 2017 from www.premiumtimes.com

Oduah, C. (2017). 50 years on: Nigeria's Biagra succession of movement: Retrieved on October 12, 2017 from www.aljazeera.com/indept/feature.

Odumegwu Ojukwu, Emeka (1989). Because I am involved. Ibadan: Spectrum Books Ltd. 
Okafor, V. E (2010). Nation-building in Nigeria: Problems and prospects. Awka, Bammy print.

Okwodu, R. N (1979) “O” level Government for West Africa".Macmillan publishers, London.

Olaniyi, M. (2009). Theories of Development and Africa: A Theoretical and Historical Critique: Paper presented at the Faculty of Social Sciences, Nnamdi Azikiwe University, Awka.

Olufemi, Kola (2005). "The Quest for the "True Federalism" and Political Restructuring: Prospects and Constraints." In Ebere Onwudiwe and Rotimi T. Suberu (eds). Nigeria federalism in Crisis: Critical Perspectives and Political Options. Ibadan: Programme on Ethnic and Federal Studies. University of Ibadan.

Omodia, S. M \& Muhammed, A. (2016).Poverty and national security in Nigeria fourth Republic, Journal of Political inquiry, 2(1) pp. 44-60.

Onyeziri, Fred (2001). "Critical Options for Managing the National Question in Nigeria.'In Eghosa Osaghae and Ebere Onwudiwe (Eds.).Management of the National Questions. Ibadan: The Lord's Creation.

Ojo, Emmanuel O. (2005) "Federalism and Nation Cohesion in Nigeria," In Ebere Onwudiwe and Rotimi Suberu (Eds). Nigeria Federalism in Crisis: Critical Perspectives and Political Option. Ibadan: Programme on Ethnic and Federal Studies, University of Ibadan.

Ojo, Emmanuel O. (2009). Mechanisms of National Integration in a Multi-Ethnic Federal State: The Nigerian Experience. Ibadan: John Archers (Publisher) Ltd.

Seers, D. (1969) "The meaning of Development" Paper presented at the Eleventh World Conference of the Society for International Development. New Delhis India. 
Shamaije, T. A and Nyionge, E.A (2012).Citizenship education and the Nigerian State. Markurdi, Destiny Venture.

Stiglitz, J. (1997). "An Agenda for Development and the Twenty First Century" A key note. Address to the Ninth Annual World bank Conference on Development Economics. Washington DC April 30, 1997.

Tarlton, Charles (1965). "Symmetry as Element of Federalism: A Theoretical Speculation." Publius: The Journal of Federalism. Vol. 27. No. 4. 